Original

\title{
CD3+ and Pax5+ Lymphocytes were not Found in the Epidermis and Adnexal Epithelia of Normal Skin from the Dorsolateral Thorax of Dogs
}

\author{
CD3 陽性・Pax5 陽性リンパ球は犬の胸部から採材された \\ 正常皮膚の表皮や付属器上皮からは検出されなかった
}

\author{
Mitzi D. Clark ${ }^{1)}$, Danny W. Scott ${ }^{1)}$, Longying Dong ${ }^{2)}$, Sean P. McDonough ${ }^{2)}$ \\ ${ }^{1)}$ Department of Clinical Sciences and \\ ${ }^{2)}$ Department of Biomedical Sciences, College of Veterinary Medicine, Cornell University
}

Received March 16, 2012 and accepted May 20, 2012

\begin{abstract}
A small population of resident T-lymphocytes is present in the healthy epidermis of skin from humans, mice, cattle, and sheep. Resident lymphocytes were not found in the epidermis or adnexal epithelia of healthy skin from cats and horses. Skin-biopsy specimens from the normal skin of the dorsolateral thorax from 29 dogs were examined histologically and immunohistochemically for the presence of lymphocytes, CD3+ (T-lymphocytes), and Pax5+ (B-lymphocytes) cells in the epidermis and adnexal epithelia. All examinations were negative. It appears that lymphocytes rarely occur, or occur in very small numbers, in the epidermis and adnexal epithelia of normal dog skin.
\end{abstract}

Key words: dog, skin, resident epithelial lymphocytes

要 約：健常な表皮には少数の $\mathrm{T}$ 細胞が常在することが，これまでヒト，マウス，ウシおよびヒツ ジで報告されている。しかしネコやウマでは，同様の細胞は表皮や付属器上皮に認められない。そ こでイヌの表皮や付属器上皮におけるリンパ球，CD3 陽性細胞（T細胞）ならびに Pax5 陽性細胞 （B 細胞）の存在を調べるため，29頭のイヌ胸背部から生検により採材した健常皮膚を組織学的お よび免疫組織化学的に解析した。その結果全ての組織において，前述の細胞はいずれも認められな かった。以上より，健常イヌの表皮にはリンパ球はほとんど認められないか，存在してもごくわず かな数であることが示唆された。

キーワード：イヌ, 皮膚, 上皮定住リンパ球

(Jpn J Vet Dermatol 2012, 18 (4): 233-237)

\section{Introduction}

Resident lymphocytes in human epidermis were likely first described by Kondo in 1922. Studies have demonstrated that resident epidermal lymphocytes in humans are CD3+ (pan T-cell marker) T-lymphocytes and

* Correspondence to: Danny W. Scott (Department of Clinical Sciences, College of Veterinary Medicine, Cornell University), Ithaca, New York 14853-6401, USA

FAX +1-607-253-3534 E-mail: shb3@cornell.edu occur rarely in the epidermis and adnexal epithelia ${ }^{9,10,24)}$. Resident epidermal CD3+ T-lymphocytes have also been described in the mouse ${ }^{26)}$, sheep ${ }^{11)}$, and cow ${ }^{12)}$, and are found in very small numbers. Two recent studies failed to identify resident lymphocytes in the epidermis and adnexal epithelia of normal skin from cats ${ }^{27)}$ and horses $^{28)}$.

Lymphocytes have been immunophenotyped in numerous inflammatory dermatoses of the dog, and have been shown to be T-cells ${ }^{1,7,13,15,16,18)}$. However, 
epidermal lymphocytes generally have not been demonstrated in normal skin (face, groin, axilla, thorax) save for the lip, from very small numbers of $\operatorname{dogs}{ }^{6,18)}$. Normal skin (dorsal paw, lateral thorax, axilla, groin; 4 skin sections per site, 16 sections total) was studied from only $3 \mathrm{dogs}^{18)}$. CD3+ cells were "rarely" seen in the epidermis in 1 of 16 sections (anatomic site not specified). To the authors' knowledge, the occurrence of resident lymphocytes in the adnexal epithelia of normal dog skin has not been investigated.

B-lymphocytes have not been found in normal human and murine skin ${ }^{4,23,26)}$. To the authors' knowledge, B-lymphocytes have not been detected in normal canine skin. Paired box (Pax) protein 5 has been recently reported to be a B-lymphocyte (not plasma cell) marker in humans and $\operatorname{dog}^{2,29)}$.

The purpose of this study was to determine the prevalence of $\mathrm{CD} 3+$ and Pax5+ cells in the epidermis and adnexal epithelia in skin-biopsy specimens from 29 dogs with normal skin.

\section{Materials and Methods}

\section{Sample collection}

Archival samples of normal skin from 29 dogs submitted to the Section of Anatomic Pathology for necropsy in 2010 were used in this study. The 29 dogs ranged in age from $<1$ month to 15 years old, included 15 males and 14 females, and represented several breeds and mongrels. All skin samples were taken from the dorsolateral thorax using a 6-mm biopsy punch. Samples were then formalin-fixed and paraffin-embedded. Serial sections ( $4 \mu \mathrm{m}$ thick) from each block were stained with hematoxylin and eosin and with antibodies against CD3 and Pax5.

\section{Histological evaluation}

Sections stained with hematoxylin and eosin (1 section per dog) were examined independently by 2 of the authors (MDC and DWS). Epidermis and epithelia of all hair follicles, sebaceous glands, and epitrichial sweat glands were examined for the presence of lymphocytes. The number of pilosebaceous units per section was recorded.

\section{Immunohistochemical investigation}

Immunohistochemistry for $\mathrm{CD} 3$ and Pax 5 was performed as previously described ${ }^{2,7,29)}$. Briefly, sections were mounted (ProbeOn Microscope Slides, Fisher Scientific Co., Bridgewater, New Jersey, USA) and deparaffinized. Antigen retrieval was tested using a variety of methods. The best antigen retrieval method was to steam tissue sections in citrate buffer $(0.01 \mathrm{~mol} /$ $\mathrm{L}, \mathrm{pH} 9.0)$ for 5 minutes at higher power $(800 \mathrm{~W})$ and for 15 minutes at medium power $(300 \mathrm{~W})$. The sections were incubated with rabbit antihuman polyclonal CD3 antibody (Dako North America, Carpenteria, California, USA) at a $1: 100$ dilution of $500 \mu \mathrm{g} / \mathrm{ml}$ stock solution, and rabbit antihuman monoclonal Pax5 antibody (Thermo Fisher Scientific, Waltham, Massachusetts, USA) which was prediluted and in a ready-to-use form, and stained using a standardized streptavidin-biotin immunoperoxidase technique. The chromagen was Nova Red.

Normal canine lymph node and canine brain from the same period served as positive and negative tissue controls, respectively. Additionally, diseased canine skin (Malassezia dermatitis with epidermal and dermal lymphocytes and dermal plasma cells present on hematoxylin and eosin-stained sections ${ }^{15)}$ was processed in an identical fashion to the samples in question to serve as a positive tissue control. Diseased canine skin also served as a negative tissue control, when processed by substituting the primary antibody with nonimmune rabbit serum.

\section{Results}

The number of pilosebaceous units per hematoxylin and eosin-stained section ranged from 6-22 (total number examined $=313$ ). No lymphocytes were seen in the hematoxylin and eosin-stained sections, and no $\mathrm{CD} 3+$ or Pax 5+ cells were present in the epidermis and adnexal epithelia. The agreement between the 2 histological and immunohistochemical assessments was $100 \%$. Positive and negative controls reacted appropriately (Figs. 1 and 2). The lymphocytes and plasma cells in the sections of Malassezia dermatitis were CD3+ (Fig. 3) and Pax5-, respectively.

\section{Discussion}

Resident epidermal T-lymphocytes are a component of the skin-associated lymphoid tissue and skin immune system in humans and mice, ${ }^{45}$. It has been suggested that, while present in very low numbers, resident 


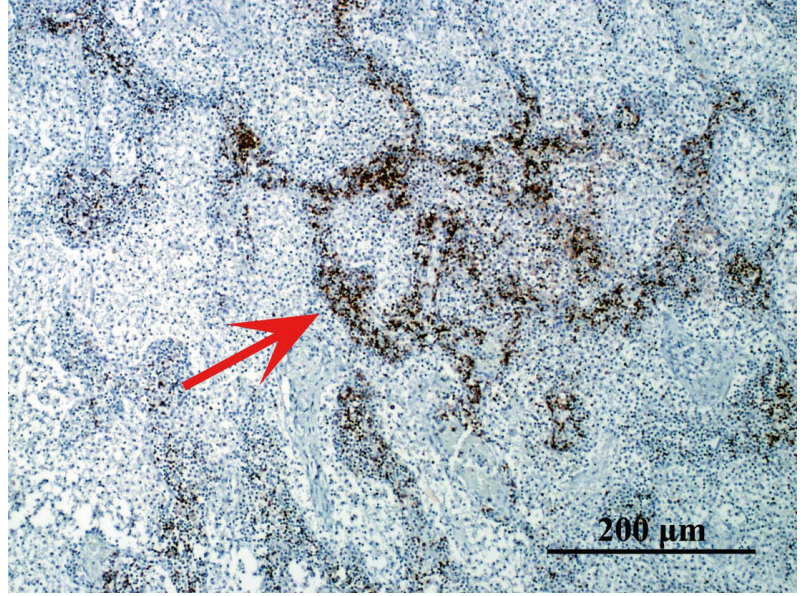

Fig. 1. Normal canine lymph node. CD3+ lymphocytes (arrow) are predominantly present outside germinal centers (Nova Red).

T-lymphocytes have varied important immunologic functions, to include disease mediation and protective roles $^{21)}$.

In humans, most inflammatory dermatoses contain predominantly T-lymphocytes ${ }^{9,10,23)}$. In the dog, numerous reports have described T-lymphocytes in inflammatory dermatoses. CD3+ lymphocytes have been documented in canine epidermis and/ or adnexal epithelium in graft-versus-host disease and erythema multiforme ${ }^{1)}$, exfoliative cutaneous lupus erythematosus ${ }^{5)}$, vesicular cutaneous lupus erythematosus ${ }^{13)}$, alopecia areata ${ }^{17)}$, Malassezia dermatitis $^{15)}$, demodicosis ${ }^{7}$, leishmaniosis ${ }^{19)}$, and atopic dermatitis $^{18,22)}$.

Resident epidermal lymphocytes in humans and mice are not of the B-cell immunophenotype ${ }^{4,23,26)}$. Similarly, they are not a major component of most inflammatory dermatoses in humans or dogs. Pax 5 has been evaluated as a pre-plasma cell, B-lymphocyte marker for canine lymphocytes ${ }^{2,29)}$. We could find no reports on the occurrence of Pax5+ B-lymphocytes in normal skin or inflammatory dermatoses from dogs.

We elected to use Pax5 as a B-lymphocyte marker because it is not expressed by plasma cells ${ }^{2,29)}$. Although CD79a and CD20 are also B-lymphocyte markers in dogs, they both can also be expressed by plasma cells ${ }^{20)}$.

To our knowledge, this is the first study to investigate normal canine skin for (1) the presence of lymphocytes in adnexal epithelia (hair follicle, sebaceous gland, epitrichial sweat gland), and (2) the presence of Pax5+ lymphocytes in epidermis and adnexal epithelia. In

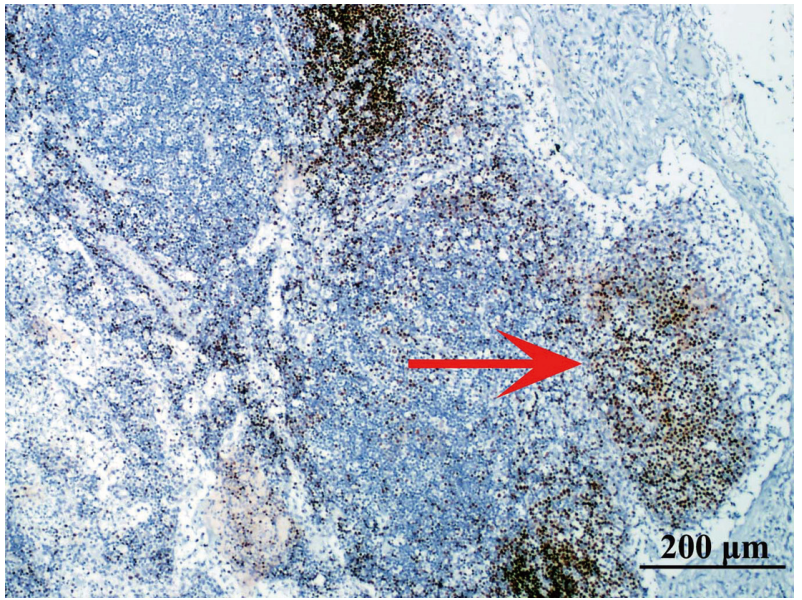

Fig. 2. Normal canine lymph node. Pax5+ lymphocytes (arrow) are predominantly present within germinal centers (Nova Red).

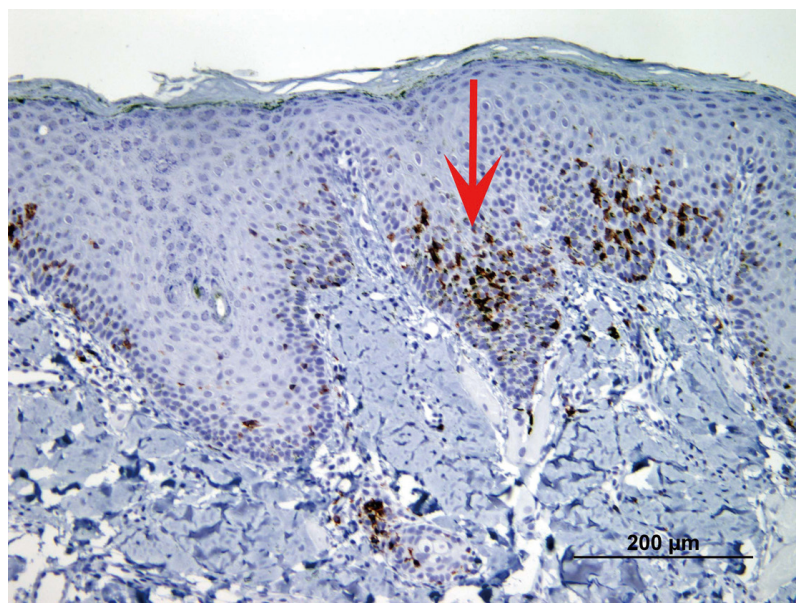

Fig. 3. Skin-biopsy specimen from a dog with Malassezia dermatitis. Note CD3+ lymphocytes (arrow) within hyperplastic epidermis (Nova Red).

addition, our study concerns the largest cohort of dogs examined to date for the presence of resident epithelial lymphocytes. We found neither CD3+ nor Pax5+ cells in the epithelia of normal dog skin. In normal human epidermal sheet preparations and normal ovine epidermis, T-lymphocytes numbered $<0.25 / \mathrm{mm}^{3}$ and approximately $10 / \mathrm{cm}^{2}$, respectively ${ }^{8,11)}$. It may be that resident epidermal lymphocytes occur in very small numbers in normal canine skin, but our sample size was not adequate to detect them.

In this study, only skin from the dorsolateral thorax was examined. It is possible that the presence and number of resident lymphocytes vary with body site. For instance, perhaps body regions with more environmental 
exposure, such as glabrous regions, lips, or pawpads would yield different results. However, previous studies in humans generally detected no variation when multiple regions of skin were sampled, to include the breast, thigh, arm, chest, back, abdomen, eyelid, face, neck, scalp, and buttock ${ }^{3,10)}$. In addition, other investigators also failed to demonstrate epidermal lymphocytes in normal canine skin from various sites (e.g., face, groin, axilla, thorax, dorsal paw) in smaller numbers of dogs than investigated in the present study ${ }^{6,18,22)}$.

In conclusion, $\mathrm{CD} 3+$ and Pax5+ lymphocytes were not found in the epidermis and adnexal epithelia of normal canine skin from the dorsal lateral thorax. It appears that lymphocytes rarely occur, or occur in very small numbers, in the epidermis and adnexal epithelia of normal dog skin. The presence of lymphocytes in these structures should, therefore, be considered abnormal in canine skin-biopsy specimens.

\section{References}

1) Affolter, V.K., Moore, P.F. and Sandmaier, B.M. 1995. Immunohistochemical characterization of canine acute graft-versus-host disease and erythema multiforme. Adv. Vet. Dermatol. 3: 103-115.

2) Agostinelli, C., Sabattini, E., Gjorret, J.O., Righi, S., Rossi, M., Manchi, M., Piccaluga, P.P., Bacci, F., Marafioti, T., Bettini, G., Falini, B. and Pileri, S.A. 2010. Characterization of a new monoclonal antibody against Pax5/BASP in 1525 paraffinembedded human and animal tissue samples. Appl. Immunohistochem. Mol. Morphol. 18: 561-572.

3) Alaibac, M., Morris, J., Yu, R. and Chu, A.C. 1992. T-lymphocytes bearing the $\gamma \delta$ T-cell receptor: a study in normal human skin and pathological skin conditions. Br. J. Dermatol. 127: 458-462.

4) Bos, J.D., Zonneveld, I., Das, P.K., Krieg, S.R., van der Loos, C.M. and Kapsenberg, M.L. 1987. The skin immune system: SIS: distribution and immunophenotype of lymphocyte subpopulations in normal skin. J. Invest. Dermatol. 88: 569-573.

5) Bryden, S.L., White, S.D., Dunston, S.M., Burrows, A.K. and Olivry, T. 2005. Clinical, histopathological, and immunological characteristics of exfoliative cutaneous lupus erythematosus in 25 German short-haired pointers. Vet. Dermatol. 16: 239-522.

6) Cannon, A.C., Olivry, T. and Ihrke, P.J. 1996.
Gamma delta T-cells in normal and diseased canine skin. Adv. Vet. Dermatol. 3: 137-143.

7) Caswell, J.L., Yager, J.A., Ferrer, L. and Weir, J.A.M. 1995. Canine demodicosis: a re-examination of the histopathologic lesions and description of the immunophenotype of infiltrating cells. Vet. Dermatol. 6: 9-19.

8) Cooper, K.D. 1992. Skin-infiltrating lymphocytes in normal and disordered skin: activation signals and functional roles in psoriasis and mycosis fungoides-type cutaneous $\mathrm{T}$ cell lymphoma. $J$. Dermatol. 19: 731-737.

9) Dupuy, P., Heslan, M., Fraitag, S., Hercend, T., Dubertret, L. and Bagot, M. 1990. T-cell receptorgamma/delta bearing lymphocytes in normal and inflammatory human skin. J. Invest. Dermatol. 94: 764-768.

10) Foster, C.A., Yokozeki, H., Rappersberger, K., Koning, F., Volc-Platzer, B., Rieger, A., Coligan, J.E., Wolff, K. and Stingl, G. 1990. Human epidermal T-cells predominantly belong to the lineage expressing alpha/beta T-cell receptor. $J$. Exper. Med. 171: 997-1013.

11) Gorrel, M.D., Townsend, W.L. and Ladds, P.D. 1997. The distribution of lymphocyte subpopulations in normal and acanthotic ovine skin. Vet. Immunol. Immunopathol. 44: 151-167.

12) Hein, W.R. and Dudler, L. 1997. TCR cd+ cells are prominent in normal bovine skin and express a diverse repertoire of antigen receptors. Immunol. 91: 58-64.

13) Jackson, H.A., Olivry, T., Berget, F., Dunston, S.M., Bonnefont, C. and Chabanne, L. 2004. Immunopathology of vesicular cutaneous lupus erythematosus in the rough collie and Shetland sheepdog: a canine homologue of subacute cutaneous lupus erythematosus in humans. Vet. Dermatol. 15: 230-239.

14) Kondo, K. 1922. Studien uber die Wanderzellen in der Haut. Jpn. J. Med. Sci. 2: 59-60.

15) Mauldin, E.A., Scott, D.W., Miller, W.H. and Smith, C.A. 1997. Malassezia dermatitis in the dog: a retrospective histopathological and immunopathological study of 86 cases (1990-1995). Vet. Dermatol. 8: 191-202.

16) Murphy, K.M. and Olivry, T. 2000. Comparison of T-lymphocyte proliferation in canine epitheliotropic lymphosarcoma and benign lymphocytic 
dermatoses. Vet. Dermatol. 11: 99-105.

17) Olivry, T., Moore, P.F., Naydan, D.K., Puget, B.J., Affolter, V.K. and Kline, A.E. 1996. Antifollicular cell-mediated and humoral immunity in canine alopecia areata. Vet. Dermatol. 7: 67-79.

18) Olivry, T., Naydan, D.K. and Moore, P.F. 1997. Characterization of the cutaneous inflammatory infiltrate in canine atopic dermatitis. Am. J. Dermatopathol. 19: 477-486.

19) Papadogiannakis, E.I., Koutinas, A.F., Saridomichelakis, M.N., Vlemmas, J., Lekkas, S., Karameris, A. and Fytianou, A. 2005. Cellular immunophenotyping of exfoliative dermatitis in canine leishmaniosis (Leishmania infantum). Vet. Immunol. Immunopathol. 104: 227-237.

20) Ramos-Vara, J.A., Miller, M.A. and Valli, V.E.O. 2007. Immunohistochemical detection of multiple myeloma 1/interferon regulatory factor 4 (MUM1/ IRF-4) in canine plasmacytoma: comparison with CD79a and CD20. Vet. Pathol. 44: 875-884.

21) Shiohara, T. and Moriya, N. 1997. Epidermal T-cells: their functional role and disease relevance for dermatologists. J. Invest. Dermatol. 109: 271275.

22) Sinke, J.D., Thepen, T., Bihari, I.C., Rutten, V.P. and Willemse, T. 1997. Immunophenotyping of skin-infiltrating T-cell subsets in dogs with atopic dermatitis. Vet. Immunol. Immunopathol. 57: 1323.

23) Smolle, J., Ehall, R. and Kerl, K. 1985. Inflammatory cell types in normal human epidermis: an immunohistochemical and morphometric study. Acta Dermato-Venereol. 65: 479-483.

24) Spetz, A.L., Strominger, J. and Groh-Spies, V. 1996. T-cell subsets in normal human epidermis. Am. J. Pathol. 149: 665-674.

25) Streilein, J.W. 1983. Skin-associated lymphoid tissues (SALT): origins and functions. J. Invest. Dermatol. 80: 12s-16s.

26) Tigelaar, R.E. and Lewis, J.M. 1995. Immunobiology of mouse dendritic epidermal T cells: a decade later, some answers, but still more questions. $J$. Invest. Dermatol. 105: 43s-49s.

27) Tranchina, M.M., Scott, D.W. and McDonough, S.P. 2010. CD3+ and BLA.36+ cells do not occur in the epidermis and adnexal epithelia of normal skin from the dorsolateral trunk of cats. J. Feline Med. Surg. 12: 790-793.

28) Tranchina, M.M., Scott, D.W. and McDonough, S.P. 2010. CD3+ and BLA.36+ cells do not occur in the epidermis and adnexal epithelia of normal equine skin. Equine Vet. 42: 471-473.

29) Willman, M., Müllauer, L., Guija de Arespacochaga, A., Reifinger, M., Mosberger, I. and Thalhammer, J.G. 2009. Pax 5 immunostaining in paraffinembedded sections of canine non-Hodgkin lymphoma: a novel canine pan preB- and B-cell marker. Vet. Immunol. Immunopathol. 128: 359365. 